\title{
Sobre trilhos: a memória revisitada pelo apito do trem a partir de um estudo com as lentes do imaginário
}

\author{
Heloisa Juncklaus Preis Moraes* \\ Luiza Liene Bressan" \\ Leidiane Coelho Jorge***
}

\section{Resumo}

A Ferrovia Tereza Cristina, principal elo entre os municípios que compõem a bacia carbonífera do sul de Santa Catarina, foi durante mais de meio século a fomentadora de sonhos de desenvolvimento da referida região. $\mathrm{O}$ apito das locomotivas e o chiar das rodas sobre os trilhos de ferro perduram na memória dos habitantes e se constituem como elementos que suscitam o imaginário partilhado pelos moradores das regiões cujas vidas foram forjadas às margens da ferrovia e que, ao ouvir e imaginar as grandes transformações que aqueles apitos poderiam trazer para o seu cotidiano ou para outras pessoas, devanearam no sonho da prosperidade. Para perceber a função imaginante a partir da imagem do trem, especialmente da simbologia do seu apito, ouvimos cinco moradores da cidade de Lauro Müller, SC, que vivenciaram as passagens das locomotivas. $\mathrm{O}$ procedimento me- todológico está fundado na pesquisa descritiva de abordagem qualitativa, a partir da mitocrítica e da observação sensível das narrativas.

Palavras-chave: Apito do trem. Imaginário. Memória. Sensibilidades.

\footnotetext{
Doutora em Comunicação Social. Docente do Programa de Pós-Graduação em Ciências da Linguagem da Universidade do Sul de Santa Catarina. Líder do Grupo de Pesquisas do Imaginário e Cotidiano (CNPq-Unisul).E-mail: heloisapreis@hotmail.com

** Mestre e doutoranda do Programa de Pós-Graduação em Ciências da Linguagem da Universidade do Sul de Santa Catarina. Docente do Centro Universitário Barriga Verde. Integrante do Grupo de Pesquisas do Imaginário e Cotidiano (CNPq-Unisul). E-mail: luizalbc@yahoo.com.br

**** Mestre e doutoranda do Programa de Pós-Graduação em Ciências da Linguagem da Universidade do Sul de Santa Catarina. Integrante do Grupo de Pesquisas do Imaginário e Cotidiano (CNPq-Unisul). E-mail: ley_ddy@hotmail.com
}

Data de submissão: jan. 2018 - Data de aceite: fev. 2018 http://dx.doi.org/10.5335/rdes.v14i1.7381 


\section{Primeiras palavras}

Começamos dizendo que trataremos de sensibilidades. Nosso estudo, na interface dos processos culturais, da história, da memória afetiva e do imaginário, busca revelar a aura coletiva que paira no sul de Santa Catarina, quando falamos da Ferrovia Tereza Cristina. Neste estudo, especialmente por estarmos ancoradas na perspectiva teórica da antropologia do imaginário, buscamos o mote do apito do trem como produtor de imagens e sentidos. O som como memória afetiva que cria imagens de pertencimento, de sonhos, de vínculo e, também, saudosismo. É esta aura coletiva que buscamos regatar pela memória, pois

[...] o imaginário é não somente explorado como um todo acabado, analisável em séries fixas, mas também, como um processo constante de equilibração e desiquilibração no qual os procedimentos experimentais podem positivamente intervir (DURAND, 1984, p. 26).

Iniciamos este estudo com as palavras de Durand, pois é a memória interpelada por simbologias sonoras evocadas pelo som do apito do trem na região carbonífera do sul de Santa Catarina que relacionaremos com o imaginário férreo da região.

Cabe informar que nos referimos a um percurso específico desta ferrovia: o trajeto entre Lauro Müller e Tubarão, que serviu para transportar o carvão mineral produzido no município das encostas da Serra do Rio do Rastro, Lauro
Müller, ao porto de Imbituba. Além do transporte de cargas, havia o trem de passageiros, durante um longo período, a única via de acesso para as cidades vizinhas, além, claro, do transporte de tração animal (ZUMBLICK, 1987).

As obras da construção da referida ferrovia tiveram início em 18 de dezembro de 1880, partindo do porto de Imbituba ao lugar denominado Minas, hoje Lauro Müller, com um ramal para Laguna, em Santa Catarina. Em $1^{0}$ de setembro de 1884, a linha foi toda entregue ao tráfego, sendo que a linha principal tinha pouco mais que 110 quilômetros e o ramal 5,2 , ou o total de 116,3 quilômetros. A partir de sua inauguração, a Ferrovia Tereza Cristina se constituiu na principal forma de ligação entre os municípios da encosta da serra ao litoral (ZUMBLICK, 1987).

Em 1971, toda a região e, principalmente, o município de Lauro Müller passaram por forte destruição provocada pela cheia do Rio Tubarão, cuja nascente se localiza nas encostas da serra. A malha ferroviária do município e a exploração do carvão sofreram fortes impactos com a catástrofe natural, mas persistiram até 1974, quando uma nova cheia provocou a destruição total da ferrovia que ficava às margens do rio. A partir dessa data, a Ferrovia Tereza Cristina, neste trecho, deixou de existir. Em seu lugar, restam as memórias das pessoas que moram próximas à ferrovia e que dela se lembram, de forma significativa, do trem e de seu apito. 
A passagem do trem, marcada pela sonoridade de seu apito, pode ser compreendida como um ritual de passagem. As coisas aconteciam antes e depois da passagem do trem, o que nos reporta a uma vivência mítica, que o enfoque antropológico da teoria do imaginário nos ajuda na compreensão. Como o ritmo da vida se marcava pela passagem do trem, é importante que signifiquemos o termo passagem, compreendido, aqui, por tudo o que passa de um estado para o outro. Move-se de um ponto para o outro. O movimento é ininterrupto. "É uma imagem altamente espacial” (AUGRAS, 1984, p. 35). Essa imagem espacial está marcada na memória da gente que nesta região vive, que rememora a vida dos tempos do trem, de seu apito ao partir da estação e ao chegar a ela, do apito que indicava os pontos em que se parava para pegar os passageiros, do apito do trem carregado de carvão, do apito que avisava que era hora do almoço. Sim, o apito do trem marcava as horas. O tempo era marcado pelo apito do trem. As boas e as más notícias chegavam e partiam com o apito do trem. Como nos ensina Augras, "toda passagem é perigosa. Toda passagem é angustiante. Toda passagem é necessária" (1984, p. 36), e, acrescentamos: vemos que a passagem do trem, marcada pelo seu apito, também marcava a passagem do tempo nesta região.

Metodologicamente, orientamos nossa pesquisa por meio da entrevista semiestrutura e analisamos os relatos de cinco pessoas entre 58 anos e 88 anos que, de alguma forma, experimen- taram sensorialmente a passagem do trem nesse trecho da ferrovia que já não mais existe, desde o ano de 1974 . O relato está fundado na pesquisa descritiva de abordagem qualitativa, a partir da observação sensível das narrativas (MAFFESOLI, 2005) e da mitocrítica (DURAND, 2002), como apresentaremos adiante.

\section{Memória e história: quando a lembrança é o que se tem}

A memória é um instrumento precioso em que o imaginário se manifesta e (re) constrói as ações simbólicas cotidianas. Absorvemos e carregamos durante nosso trajeto antropológico emoções, sensações, experiências que, em sua maioria, são motivadas e/ou embaladas por melodias que marcam momentos e imprimem um imaginário de sonoridades que delimitam um tempo, realçam as estações, convidam ao sonho, aludem à poesia, remetem ao inesperado, reforçam a expectativa e a ansiedade, anunciam o lazer e o descanso e avisam o início e o fim da jornada de trabalho diária. Muitos são os sons que nos informam diariamente e passam a constituir nosso imaginário. É a memória que revela os sons que permeiam as fases de nossa vida e permitem ativar as sensações do vivido e o temor ou a expectativa pelo devir.

Assim, cotidianamente, as badaladas do sino da igreja anunciam a celebração da vida ou da morte nos bairros; a 
sineta e hoje o sinal eletrônico indicam na escola a hora da entrada, da saída e o tão esperado recreio. As sirenes dos bombeiros, da polícia e das ambulâncias evidenciam o perigo eminente. No avião, temos o sinal sonoro para indicarque o piloto vai falar, que recebe toda a atenção ao soar. $\mathrm{O}$ apito do trem anuncia que a jornada de trabalho e mais um dia rotineiro começam, ao mesmo tempo em que alude, para outros, as possibilidades de viver o sonho e vislumbrar o desconhecido pelo qual os trilhos podem nos levar. É esse som, em especial, que motiva esse trabalho. $\mathrm{O}$ apito do trem ativa as memórias e revela o imaginário de tempos passados, ressignificados e revividos nas ações simbólicas praticadas no presente. Durand salienta que,

[...] longe de estar às ordens do tempo, a memória permite um redobramento dos instantes e um desdobramento do presente; ela dá uma espessura inusitada ao monótono escoamento do devir, e assegura nas flutuações do destino a sobrevivência e a perenidade de uma substância (2002, p. 402).

A memória carrega os vestígios que subsidiam a atualização do imaginário e permitem que as situações imaginárias, por meio das ações simbólicas praticadas pelos indivíduos, convertam arquétipos em mitos e os materializam nas situações vividas no cotidiano. Prieto, Filho e Brant descrevem que a vida vivida

[...] se transforma em narrativa sempre que contamos e transmitimos nossas experiências mais marcantes. Assim, nossa experiência se incorpora ao acervo do outro, como incorporamos à nossa memória as inúmeras narrativas que ouvimos todos os $\operatorname{dias}(2011$, p. 59).
As memórias vão se constituindo na medida em que as narrativas, os saberes, os fazeres e os cantos são repetidos e, pelas constantes situações que recorremos a elas, acabam ganhando efeito de sentido, desde que sejam acessados elementos a concreção. A memória pode ser ativada, como nos alerta Nora:

Os lugares de memória nascem e vivem do sentimento que não há memória espontânea, que é preciso criar arquivos, que é preciso manter aniversários, organizar celebrações, pronunciar elogios fúnebres, notórias atas, porque essas operações não são naturais. É por isso a defesa, pelas minorias, de uma memória refugiada sobre focos privilegiados e enciumadamente guardados nada mais faz do que levar a incandescência à verdade de todos os lugares de memória. Sem a vigilância comemorativa, a história depressa os varreria. São bastiões sobre os quais se escora. Mas se o que eles defendem não estivesse ameaçado, não se teria, tampouco, a necessidade de construí-los. Se vivêssemos verdadeiramente as lembranças que eles envolvem, eles seriam inúteis, e se, em compensação, a história não se apoderasse deles para deformá-los, transformá-los, sová-los e petrificá-los eles não se tornariam de memória. É este vai e vem que os constitui: momentos de história arrancados do movimento da história, mas que lhe são devolvidos. Não mais inteiramente a vida, nem mais inteiramente a morte, como as conchas na praia quando o mar se retira da memória viva (NORA, 1993, p. 13).

Ferreira Santos e Almeida firmam que a "investigação sobre o imaginário, processos simbólicos, mitologia, hermenêutica simbólica numa perspectiva mais antropológica, e, portanto, mais educativa" (2012, p. 7) é caminho possível para se empreender uma pesquisa. São veredas pelas quais se encontram 
preciosidades que permeiam terrenos conceituais, caminhos e sendas epistemológicas. Assim, este estudo propõe uma aproximação dos estudos da memória, mais especificamente da memória afetiva ativada pelo som do apito do trem.

A construção da ferrovia às margens do Rio Tubarão sempre foi descrita como utópica, conforme constatamos nas palavras de Zumblick:

Deixemos, porém, que técnicos ingleses e o ardor dos bisonhos turmeiros acordem o basbaque da população beira linha que, envolta ao marasmo em que definha, olha esbugalhada tão fascinante atividade. E, que mais e mais espetem estacas, tracem retas e curvas e desmontem ondulações, varando banhados e rios. Em breve, pousadas em dormentes, paralelas de ferro figurariam como promessas de novos tempos que fariam emergir todo o sul de Santa Catarina (1987, p. 28).

Pela exposição do pesquisador, percebemos que a construção da ferrovia era um sopro de esperança para as populações que moravam às margens do rio. A ferrovia e, posteriormente, as máquinas a vapor, com seus apitos estridentes, eram expressões da chegada do progresso que a região tanto almejava. As pessoas que vivenciaram esse período construíram um imaginário, resguardado pelas memórias que ainda sobrevivem, apesar de a ferrovia não mais existir. $\mathrm{O}$ apito do trem é um dos artefatos que evoca a memória e permite também entender a identidade cultural da região, pois a memória é um elemento essencial do que se costuma chamar identidade, individual ou coletiva, cuja busca é uma das atividades fundamentais dos indivíduos e das sociedades de hoje, na febre e na angústia (LE GOFF, 2003, p. 469).

Teixeira (2011), em Ferrovia Tereza Cristina - uma viagem ao desenvolvimento, apresenta dados históricos, a ferrovia como fator de progresso à região, e os usos e costumes a partir da sua construção. Rico material de pesquisa de muitos anos, dá pistas da formação de um imaginário. "Eis que a Teresa Cristina aqui está desde os tempos do império, quando não se conhecia ainda o motor a explosão, a luz elétrica, o telefone e o avião" (TEIXEIRA, 2011, p. 11). A proprietária da ferrovia, até o ano de 1902, quando vendida ao governo brasileiro, era a inglesa The Donna Thereza Christina Railway Company. Os relatos mostram a grandeza da obra. Enquanto os materiais, como dormentes, ferro e cimento, bem como todo capital de investimento e engenharia, vinham da Inglaterra, a mão de obra foi de imigrantes italianos, já acostumados com a floresta e o trabalho pesado. ${ }^{1}$ As pessoas desta região têm história para contar sobre a ferrovia, sua construção ou a passagem do trem.

Nossa busca é saber que afetos o apito do trem provoca e de que maneira formam uma ambiência simbólica, uma aura coletiva, pois as paisagens sonoras despertam narrativas. "Por não trabalhar com a imagem reconhecida, e sim com a imagem que ocupa a memória do 
destinatário, as possibilidades sonoras alcançam o infinito. Por imagem entende-se o conjunto de informações visuais que produzem um efeito de realidade", afirma Abreu (2014, p. 3) sobre seu estudo dos efeitos de sentido no imaginário, a partir de narrativas radiofônicas.

É pela memória que podemos revisitar um tempo vivido. Para Durand, "a memória - como imagem - é essa magia vicariante pela qual um fragmento existencial pode resumir e simbolizar a totalidade do tempo reencontrado" (2002, p. 403). Percebemos, pelas palavras do autor, que a memória tem caráter fundamental ao imaginário que é ser eufemismo. Esta relação entre imaginação e temporalidade, motivadora de representações e novas vivências, está descrita nas palavras de Durand:

Longe de estar do lado do tempo, a memória, como o imaginário, ergue-se contra as faces do tempo e assegura ao ser, contra a dissolução do devir, a continuidade da consciência e a possibilidade de regressar, de regredir, para além das necessidades do destino. É essa saudade enraizada no mais profundo e no mais longínquo do nosso ser que motiva todas as nossas representações e aproveita todas as férias da temporalidade para fazer crescer em nós, com a ajuda das imagens das pequenas experiências mortas, a própria figura da nossa esperança essencial (2002, p. 403, grifo do autor).

$\mathrm{O}$ apito do trem, ainda que não soe mais, traz lembranças? Há um contágio afetivo instaurado por cenas de uma passado que são rememoradas? É desta memória afetiva que voluntariamente tem uma afeição passada que Titchener define por memória afetiva: "podemos relacionar o termo memória como o local em que a afeição pode ressurgir" (1895 apud BRESSAN JUNIOR, 2017, p. 74). Bressan Júnior destaca que a memória afetiva é

[...] aquela composta por experiências emocionais e afetivas, constituindo um local onde um sentimento ressurge através de uma recordação (2017, p. 74).

Sendo assim, o autor, que chega a criar a noção de memória teleafetiva para os estudos de memória e televisão, esclarece-nos que, "para que se construa uma memória afetiva, é preciso ter elementos que provoquem certas emoções através dos afetos obtidos pela situação vivenciada no passado e de como nos encontramos no presente" (BRESSAN JUNIOR, 2017, p. 74), e um fator que evoca a afetividade é a recordação de um tempo que não volta mais. Voltemos ao subtítulo da seção: quando a lembrança é o que se tem. Dizemos mais, a lembrança afetiva é o que se tem presente no imaginário em relação à rede ferroviária, e o simbolismo do apito da locomotiva suscita narrativas que forjam este imaginário, como discutiremos a seguir.

\section{Imaginário e memória afetiva: entrelaçando os fios}

O império da imagem é forjado pela representação afetiva, porque vivida. $\mathrm{O}$ ser humano imagina e atribui significado às coisas, e é a partir do imaginário que vai formando as suas ações no cotidiano. O imaginário é uma instância mediadora 
e organizadora das experiências humanas. A função da mente, a imaginação, exerce a faculdade de dar sentido ao mundo, e o raciocínio

[...] permite analisar, assim como compreender os fatos e a relação existente entre eles. Logo, imaginação e razão fazem parte desse cenário simbólico (GOMES, 2013, p. 20).

Em A imaginação simbólica (1988), Durand nos esclarece que há duas formas de representar o mundo: imaginação direta e imaginação indireta. Aquela diz respeito à uma imaginação reprodutora, tal como a coisa aparece em nossa mente, evocando objetos conhecidos de vivências passadas. A indireta diz respeito à imaginação criadora, ao devaneio, às fantasias e à criação de outras imagens. Assim, as imagens que se formam são sempre cheias de sentido, e, neste trabalho, estamos nos propondo evocar imagens por meio da contemplação do passado com uma atualização presente: contemplação de uma época vivida, narração de uma história que tem suas marcas na memória afetiva e estabelece articulações simbólicas.

Estamos interessadas na atividade da imaginação simbólica, pois o símbolo traz à cena a realidade imediata, suscitando o que estava ausente. $\mathrm{O}$ imaginário coloca o homem em relação com o mundo, com o outro e consigo mesmo. Entre os fatos históricos e as tradições, há uma aura que mobiliza o presente em função dos simbolismos e imagens do passado. Consideramos, assim, o imaginário como potência, que faz equilíbrio entre mito e história e dá um senso comum a ser partilhado. O imaginário coloca-se como reservatório semântico potencializador do cotidiano.

Consideramos que o imaginário de cada indivíduo está enraizado numa bio-história pessoal [...] que lhe proporciona a sua idiossincrasia e é igualmente levado a expandir-se, a renovar-se por meio de processos de simbolização que o fazem participar da totalidade de mundo (GOMES, 2013, p. 21).

Como já afirmamos, a memória afetiva é ativada por lembranças de algo que, tendo passado, traz nostalgia, pois, ao ser estimulada, revisita um local do passado que ainda faz sentido no presente. Propicia uma vinculação imaginária de um tempo: permite a comunhão, fomenta o pertencimento, os sentimentos comuns. Entre as versões da história e do imaginário em relação a um fato ou um período, este cobre aquela com um véu de apropriações particulares. Aí está a memória afetiva sendo ativada (e ativando imagens semanticamente atuais), pois

o imaginário não é um simples conjunto de imagens que vagueia livremente na memória e na imaginação, ele é uma rede de imagens na qual o sentido é dado na relação entre elas (GOMES-DA-SILVA; GOMES, 2010 apud GOMES, 2013, p. 12).

A chave do passado pode vir pelos gestos (ou símbolos) do presente que, por evocação, transformam-se em realização. Proust fala em constante cultural: “o passado como imaginário acessível a partir de um mecanismo qualquer de rememoração" (1982, p. 31 apud SILVA, 2017 , p. 20). O sentido se dá no imaginário, tornando o símbolo ou a imagem singular. Logo, o imaginário é estrutural 
e estruturante da realidade, do nosso cotidiano, "uma memória afetiva na parede do tempo" (SILVA, 2017, p. 18).

Pensando especialmente nas narrativas sobre o nosso tema de estudo, vale ressaltar a passagem de Silva, quando afirma que

[...] aquele que mergulha num imaginário firma uma espécie de contrato tácito com a narrativa que abraça e que o envolve. Passa a aceitá-lo como plausível. Adota-o como uma descrição aceitável de um fenômeno qualquer (2017, p. 42).

O símbolo pensado, evocado, sentido, expresso está sempre ligado a um sentido. É por este ato, o da imaginação, que o símbolo se manifesta, transbordando ao universo sensível, dando sentido à sua vida a partir de símbolos que têm vida, ou seja, duração: "a dimensão simbólica propõe coisas a imaginar a respeito das possíveis redes de significações que cada pessoa associa ao seu cotidiano" (GOMES, 2013, p. 22).

Quando tratamos da busca desta aura imaginal que congrega um lugar ou um período histórico, queremos não apenas relatar os símbolos, mas também conhecer a ética da estética que, em última análise, move uma coletividade. Araújo e Mont'Alverne (2017) trazem precioso texto sobre a importância de uma educação para a imaginação, defendendo uma ética das imagens, para refletir sobre a percepção da realidade, tal como estamos pensando, a partir de vários recortes (estrada de ferro, carvão, rio, presença indígena, colonização), a formação dos imaginários local e regional no sul de Santa Catarina.
Deixar falar é um ato de comunhão imaginária. A técnica logo apresentada é condizente com a teoria com a qual nos propomos discutir o apito do trem como gatilho simbólico de um imaginário, que funciona por identificação e significação. As sensibilidades são como pertencentes ao olhar do pesquisador. Joron (2017) discute em seu texto a proposta de Georg Simmel da sociologia como uma ciência do fútil. Ou seja, aquilo que muitas vezes não interessa como problema de pesquisa é essencial para a compreensão da realidade social.

Ferreira Santos trata da sacralidade do texto em culturas orais e nos apresenta duas ideias iniciais: a palavra e a fruição sonora. Diz-nos o autor: "podemos compreender, inicialmente, um texto como um tecido tramado de fios e urdiduras com palavras que, desta forma, dão sentido e significado a uma imagem ou idéia estampados sobre a trama" (2004, p. 14) cujas regras dariam entendimento à imagem ou à ideia por ela veiculada. Mas, "além destas combinações de palavras num tecido, o texto pode ser entendido também como tessitura, como se diz em teoria musical: combinações sonoras de timbres, freqüências e tons que se harmonizam entre si" (FERREIRA SANTOS, 2004, p. 14). Reafirma o autor que

[...] seu efeito não seria apenas semântico, no sentido de comportar significações, mas comportaria, igualmente, um valor estético, uma fruição sonora que mobiliza nossos sentidos auditivos e vibracionais (2004, p. 14).

Pois, para ele, 
há uma musicalidade no texto que nos envolve e no qual, dependendo de nossa sensibilidade, podemos perceber a intrínseca harmonia sonora com seus significados professados pelas palavras (FERREIRA SANTOS, 2004, p. 14).

O sentido dos símbolos e as sensações provocadas pela lembrança da memória afetiva da passagem da locomotiva, anunciada pelo seu apito, mostram muito da aura que envolve a ferrovia no sul de Santa Catarina. É resgate de uma imagem e de sensações: memória afetiva.

Num sentido mais restrito, imaginário é diferença individual ou grupal que recorta a ficção social ou acrescenta-lhe micronarrativas que colam seus protagonistas ao conjunto social ou dão-lhes um espaço particular dentro da ordem geral ou do sistema global de atuação histórica (SILVA, 2017, p. 142).

\section{Procedimentos metodológicos}

Nossa intenção é permitir a escuta da memória que faz o retrato de um espaço-tempo que se atualiza na memória por imagens. Há histórias que são individuais, mas sentidas coletivamente. Partimos das afirmativas de Perez, para quem "o processo das lembranças é tramado pela utilização da sensibilidade da memória, através da linguagem e dos sentidos, que cada sujeito atribui aos fatos e acontecimentos vividos em sua trajetória pessoal-social, o que torna a experiência comunicável" (2003, p. 103). O intuito é colocar em cena as narrativas que expressam a memória afetiva e o imaginário em relação à história criada pela Ferrovia Tereza Cristina, especialmente aquelas suscitadas pelo apito das locomotivas e pelo chiar das rodas sobre os trilhos de ferro. Que imagens e sensações perduram na memória dos habitantes e se constituem como elementos que suscitam o imaginário partilhado pelos moradores das regiões cujas vidas foram forjadas às margens da ferrovia?

Essa indagação percorreu nossas discussões no Grupo de Pesquisas do Imaginário e Cotidiano, cuja sala fica às margens dos trilhos da parte ainda ativa da ferrovia, na cidade de Tubarão, Santa Catarina. Foi o som do apito que despertou memórias e questionamentos. Assim, propomos analisar essas memórias em local que o apito não soa mais, justamente para investigar as imagens recorrentes nesse imaginário férreo, presente no sul catarinense. $\mathrm{O}$ ambiente pesquisado foi o município de Lauro Müller, aos pés da Serra Geral, cuja atividade econômica desde as últimas décadas do século XIX é a extração do carvão. Ouvimos cinco pessoas na faixa etária de 58 a 88 anos, por meio de uma entrevista semiestruturada, com o intuito de identificar nas memórias a imagem de um passado, tendo como isca semântica principal o apito do trem.

Intentamos um mergulho no imaginário férreo, buscando compreender suas simbologias, complexidade e articulações com o cotidiano das pessoas que o vivenciaram e ainda o experimentam por meio de lembranças. Ancoradas na razão sensível (MAFFESOLI, 2005), 
estamos certas de que gestos, olhares, silêncios, suspiros, cheiros e sons expressam os movimentos do cotidiano e nos auxiliam a entender o que, pelas vias do imaginário, chamamos de trajeto antropológico (DURAND, 2012, p. 41). Ou seja, é uma tentativa de expressar a apropriação simbólica significativa deste espaço-tempo via sonoridade do apito, cujos sentidos e memórias desencadeiam um tipo de socialidade, um sentido de pertencimento.

O procedimento metodológico para a realização do estudo está fundamentado na pesquisa descritiva com abordagem qualitativa, a partir da observação sensível (BACHELARD, 1997) das narrativas feitas com os sujeitos ouvidos. As entrevistas semiestruturadas são tidas como textos culturais sobre os quais é desenvolvida a mitocrítica, técnica de investigação do imaginário que busca identificar, por meio dos mitemas, a recorrência simbólica das imagens presentes na memória como uma atividade da imaginação simbólica. Nossa hipótese é de que o símbolo, ainda que abstrato, como o apito do trem, faz suscitar sentidos de uma realidade possível por meio de imagens.

Manifestações da imaginação simbólica no tempo e como uma forma de imaginação individual ativam um sentido partilhado coletivamente. É em busca desta força imaginante que o símbolo revela o ser descoberto, imaginado, verbalizado. $\mathrm{O}$ imaginário faz parte da condição de existir, e os símbolos, como o trem e seu apito, podem "proporcionar a análise e interpretação das imagens do ponto de vista mítico-simbólico, das utopias e das metáforas que povoam o imaginário" (GOMES, 2013, p. 17) de cada uma das pessoas ouvidas. Na dinâmica de imaginar e imaginar-se, vamos construindo narrativas de conhecimento, de realidade e de memória. Tal qual Eunice Lins (GOMES, 2013) na sua proposta de abrir o baú de símbolos em sala de aula, podemos abrir o baú do imaginário, com o intuito de perceber quais afetos as imagens provocam e de que maneira formam a ambiência simbólica de um imaginário férreo. Nossa intenção é recuperar imageticamente cenas que, presentes no imaginário, remetem a uma história e a um tempo. Vamos às narrativas.

\section{Análise e discussão dos dados da pesquisa}

Como já referenciamos nos procedimentos metodológicos, entrevistamos cinco moradores do município de Lauro Müller, nas proximidades da extinta estrada de ferro Teresa Cristina. Nossos entrevistados têm idades que variam entre 58 e 88 anos. Os participantes estão identificados pelas letras iniciais de seus nomes e sobrenomes (A. B., G. B., M. C., A. G. e O. B). São três senhoras e dois senhores. Todos moram na região há mais de 50 anos e vivenciaram o período em que a estrada de ferro foi o principal meio de deslocamento da região das encostas da serra até o litoral. Essas informarções 
respondem às duas primeiras questões do roteiro de entrevista, que tinha como objetivo conhecer por quanto tempo os entrevistados tiveram contato com a ferrovia e, de alguma forma, ouviram o apito do trem, objeto desse estudo.

Façamo-nos, então, intérpretes das memórias revividas nas entrevistas realizadas, que expressam um imaginário amparadas nas questões apresentadas por Silva, que assim nos orienta: "Como fazer o imaginário falar? Como escutar o que o imaginário tem a dizer? Como negociar com essa narrativa que interpela, expõe, revela, desvela? O diálogo com o imaginário acontece como uma interpretação do ato" (2017, p. 126). Pois, "presenciamos alguns fatos, mas não presenciamos a maior parte dos fatos sobre os quais conversamos. Confiamos, porém, nas pessoas que viveram e esses fatos, e o pensamento e o discurso cotidiano se alimentam dessa confiança social" (BOSI, 2003, p.115).

A. B., ao ser questionada sobre como a passagem do trem marcava o tempo e a vida das pessoas, fez o seguinte relato:

O primeiro apito às seis horas da manhã era para começar o dia. No verão, já estávamos na lavoura, no inverno tratávamos os animais, porque era muito frio para ir para a roça.

Outro relato interessante de A. B. mostra que não só o apito era um sinal do trem chegando, mas também a vibração dos trilhos era prática, inclusive das crianças, para sentir esta presença:
Naquele tempo tínhamos que ir à atafona para pilar o arroz e moer o milho para fazer a farinha da polenta. Íamos pela estrada de ferro até o lugar. Eram cerca de três quilômetros, e havia um corte. Então, para saber se havia a possibilidade de cruzar com o trem neste local, encostava o ouvido nos trilhos para ouvir a vibração. O pai havia ensinado desta forma.

A expectativa pela passagem do trem era de alegria; ainda que incitasse preocupação, criava laços de afeto, como nos conta G. B.:

Uma parte era bonito e outra era preocupação por causa das criações que iam no trilho e ela pegava, ela não parava. Era preocupação, mas era bonito. Quando ele apitava a gente corria para ver. $\mathrm{O}$ maquinista sempre inticava a gente e abanava. Bastante amigo.

As crianças, à época, tinham seu cotidiano marcado pela passagem do trem. Fruto desta presença, havia a necessidade de conciliar as atividades diárias com o fluxo da ferrovia, em que o apito era o grande sinal, conforme G. B.:

Geralmente tinha um horário. Então quando ele apitava era uma prevenção que a gente tinha. Tinha que ver se as crianças não estavam na beira da estrada e as criações. Era um aviso.

Também M. C. relata que

era perigoso, porque tinha criança pequena e criação. Aí eles iam para estrada e para o trilho do trem. Ele apitava, e as criações se espalhavam. Sabia que quando o trem passava eram seis horas.

Atenção especial era dada aos trechos conhecidos como cortes, quando a ferrovia passava entre paredões de rocha que foram cortados para dar passagem, como podemos perceber nos depoimentos: 
Nos cortes, às vezes, ele apitava, mas ele não parava, principalmente ali era um trecho que ele tinha que embalar no corte de pedra (G. B.).

A gente tinha medo do trem vim e a gente estar no meio do corte. Se o trem vinha, a gente subia o barranco para escapar do trem (M. C.).

Conforme as memórias revividas, o som precisava ser captado com certa antecedência, para que o perigo pudesse ser evitado. Passar nos cortes da estrada de ferro era sempre tenso, e, antes de entrar no trecho, o apito do trem era sinal de alerta.

As pessoas sabiam o tipo de transporte pelo apito, o que gerava tipos de alegria e preocupação diferentes. $\mathrm{O}$ trem de passageiros, conhecido como trem de horário, gerava expectativa de acenos, já o de carga - que não tinha parada trazia preocupação, especialmente para que os animais de criação não estivessem nos trilhos. Relatam-nos G. B.:

Geralmente era uma alegria. Aquela penca de vagões. $\mathrm{O}$ apito do trem de horário. Os apitos eram diferentes. $\mathrm{O}$ apito do trem de horário era bem diferente do trem de carga.

Também M. C. rememora a diferença dos sons:

o apito do trem de carga e do trem de passageiros era diferente. $\mathrm{O}$ apito do trem de carvão era mais comprido e o do trem de passageiros fazia pi-pi-pi.

A. G. também relembrou:

o apito era diferente, as máquinas eram diferentes. $\mathrm{O}$ trem de passageiros era menor.
Podemos ver a memória afetiva sendo mobilizada, quando o apito do trem de passageiros é retratado no depoimento de O. B.:

Tinha o trem de passageiros e o trem de carvão. Aquele que levava passageiro tinha um apito mais alegre, mais comunicativo. Já o outro era mais de alerta, porque sempre tinha criação que ia para o trilho.

O fato é que todos os entrevistados lembraram, com afeto, da passagem do trem, simbolicamente rememorada pelo seu apito: "Imagina se não lembro do apito" (O. B.) e "Desde criança, era acostumado a ouvir passar o trem de horário, como a gente chamava o trem de passageiros. Era o trem que passava cedinho, por volta das seis da manhã, e que recolhia os passageiros" (A. G.). O saudosismo é ilustrado em um "ô, que saudade!" (A. B.). No trecho da narrativa de M.C. "O apito do trem de hoje é mais fraco, antes era mais forte", podemos perceber que, ao ser estimulada, a memória traz ao presente a cena passada carregada de sentido (até mais do que o presente), porque o passado revisitado é um lugar de encantamento, marcas de um imaginário.

A passagem do trem e seu apito funcionavam como um relógio, ao dar o tom do dia. O. B. não deixa dúvidas sobre a memória dessa marcação no cotidiano, durante os anos em que a ferrovia esteve em atividade na região:

O apito era quase o nosso relógio, principalmente aquele de passageiro. Por exemplo, à tardinha, tu podia esperar que ele vinha e, pela manhã, também. 
O sinal sonoro desempenhava funções que eram conhecidas pelos moradores vizinhos à ferrovia, como nos conta A. G., dando um certo caráter solene ao apito:

Tinha o trem carvoeiro que às vezes perdia força e voltava. O trem não apita à toa. Ele só apitava se precisasse do socorro de outras máquinas ou se tinha problema na linha. Se ele viesse normal, dificilmente ele apitaria. Sempre que ele apitava era para avisar. Não era de costume ele ficar apitando por qualquer coisa nas estradas.

Pelos depoimentos, que trazem ao presente, via memória, as imagens de um passado saudoso, percebemos os principais mitemas que percorrem os depoimentos: relógio e acontecimento, a medida que podemos colocar o trem, por meio de seu sinal, como organizador do cotidiano. A recorrência dessas passagens de memória nos permite reforçar a rede semântica acerca do imaginário sobre a ferrovia. Percebemos, assim, o caráter mediado na função simbólica, pois, a partir do mitema apito do trem, derivaram-se narrativas, lembranças, afetos e saudades, formando o que temos chamado de memória afetiva. Diz-nos Wunenburger que "o imaginário serve para dotar os homens de memória fornecendo-lhes relatos que sintetizam e reconstroem o passado e justificam $o$ presente" (2007, p. 63).

Percebemos, também pelas narrativas, um elo que contempla um tempo passado, saudosista, que cria vínculo com "o hedonismo de uma antiga outrora", como diria Maffesoli (2005). Este tempo é passível de ser revisitado pela lembrança e pela capacidade de imaginar-se novamente vivenciando aquelas situações. Um símbolo, o trem e seu apito, traz à cena recorrências simbólicas que mobilizavam a vida, pois, ao rememorar aquele tempo, não é a coisa (o trem em si), mas a forma como se carrega imaginalmente seu sentido e a possibilidade de partilhá-lo.

Os relatos fazem parte de histórias de vidas de indivíduos e de um grupo cujo agenciamento de mitemas recorrentes favorece a identificação de uma "poética do imaginário" a partir da memória afetiva. A experiência descrita tem sua base no presente, pois o som do apito do trem ainda ressoa no agora; faz ligação com o passado, mas se mantém vivo, sensível, tal como descreve Husserl:

quando fazemos soar, eu o ouço como presente, mas enquanto continua a soar, ele tem um presente sempre novo, e o presente a cada vez precedente se converte num passado (1964, p. 37 apud RICOEUR, 2007, p. 50).

\section{Sobre finalizar}

Ao refletir sobre a história da estrada de ferro Tereza Cristina no trecho que compreende os municípios de Lauro Müller a Imbituba e a marca que o apito do trem deixou nas pessoas entrevistadas neste estudo, tendo como referencial as memórias revisitadas, percebemos que as experiências vivenciadas pelos participantes na constituição de seu espaço acabam por ser expressas no dinamismo do tempo. Ao rememorar o passado, o narrador o reencontra e, ao reencontrá- 
-lo, fala de si próprio, conferindo valores e significados à sua experiência. Rememorar o som do apito do trem, tanto o de passageiros quanto o de carga (neste caso, carvoeiro, por transportar carvão mineral), significou aos nossos entrevistados uma narrativa que se presenteficou, marcada por memórias afetivas que, em alguns casos, são festivas e, em outros, apreensivas. Este estudo permite-nos pensar as relações entre memória e história (ainda - ou, por isso mesmo ancoradas na perspectiva do imaginário):

[...] longe de serem sinônimos, tomamos consciência que tudo opõe uma a outra. A memória é a vida, sempre carregada por grupos vivos, e, nesse sentido, ela está em permanente evolução, aberta à dialética da lembrança e do esquecimento, inconsciente de suas deformações sucessivas, vulnerável a todos os usos e manipulações, susceptível de longas latências e de repentinas revitalizações. A história é a reconstrução sempre problemática e incompleta do que não existe mais. A memória é um fenômeno sempre atual, um elo vivido no eterno presente; a história, uma representação do passado. Porque é afetiva e mágica, a memória não se acomoda a detalhes que a confortam; ela se alimenta de lembranças vagas, telescópicas, globais ou flutuantes, particulares ou simbólicas, sensível a todas as transferências, cenas, censura ou projeções. A história, porque operação intelectual e laicizante, demanda análise e discurso crítico. A memória instala a lembrança no sagrado, a história a liberta, e a torna sempre prosaica. A memória emerge de um grupo que ela une, o que quer dizer, como Halbwachs o fez, que há tantas memórias quanto grupos existem; que ela é, por natureza, múltipla e desacelerada, coletiva, plural e individualizada. A história, ao contrário, pertence a todos e a ninguém, o que lhe dá uma vocação para o universal. A memória se enraíza no concreto, no espaço, no gesto, na imagem, no objeto. A história só se liga às continuidades temporais, às evoluções e às relações das coisas. A memória é um absoluto, e a história só conhece o relativo (NORA, 1993, p. 17).

Perceber os diversos caminhos que as memórias percorriam para narrar suas experiências e sensações nos levou a entender a necessidade de interpretar, nas narrativas orais, como são elaboradas as memórias sobre o apito do trem no município de Lauro Müller, conhecido como berço histórico do carvão nacional, onde se situou a primeira estação da estrada de ferro Tereza Cristina. Ao falar do trem, os entrevistados falaram deles mesmos. Sobretudo, porque todos nasceram na época em que o trem e o seu apito cruzavam a ferrovia, transportando pessoas e cargas, permitindo que as experiências de desenvolvimento e finalização do funcionamento do tráfego férreo no município revivessem, ainda que de forma fugaz. A história de vida dos entrevistados também foi marcada pelo apito do trem, hoje silenciado.

Percebemos que, ao sugerirmos o mitema apito do trem, acabamos despertando uma aura simbólica, perceptivelmente recorrente nas narrativas. Houve um reencontro com um tempo. Houve um contágio afetivo pela memória individual, também percebida como aura coletiva, pois as instâncias do sensível relatadas foram as mesmas. Podemos considerar o som um símbolo que trouxe à tona, via memória e via relato oral, cenas de uma realidade que fomenta um imaginário férreo existente. Vale a máxima da teoria de que o sentido se dá no imaginário. 
O trem relógio, a marcar a passagem do tempo, era anunciado pelo seu apito. Nesse sentido, o som do trem faz parte da cultura latente (PAULA CARVALHO, 1990, p. 234 apud PORTO, 2000, p. 25): o nível afetivo, de uma dimensão afetiva e simbólica da cultura de um grupo, que dá sentido e gera pertencimento a um passado e a um vínculo no presente. A perspectiva do imaginário mostra que as construções mentais podem ser eficazes em relação ao concreto, modulam nosso cotidiano. Tal como nos apresenta Maffesoli, “o imaginário é algo que ultrapassa o indivíduo, que impregna o coletivo ou, ao menos, parte do coletivo" (2005, p. 76).

É o imaginário que permite (e provoca) a relação do eu com o mundo. Pela imagem do trem, percebemos uma aura coletiva, um imaginário férreo que povoa aquela coletividade:

$\mathrm{O}$ vocábulo fundamental que corresponde à imaginação não é a imagem, é o imaginário. $O$ valor de uma imagem se mede pela extensão de sua aura imaginária. Graças ao imaginário, a imaginação é essencialmente aberta, evasiva. Ela é no psiquismo humano a experiência da abertura, a experiência da novidade (PITTA, 2005, p. 16).

Nossa proposta de pensar o apito do trem não só como mitema, mas também como imagem presente em um imaginário local leva em consideração a escuta dos sentidos, das sensibilidades. Le Breton fala da audição como "o sentido da interioridade, ela traz o mundo para o centro do indivíduo, aí aonde a visão o projeta para fora" (2016, p. 136).
$\mathrm{O}$ apito do trem não soa mais sobre os trilhos, mas continua presente na memória afetiva, vivo, símbolo de um tempo, imagem de uma época. Bacia semântica que guia o trajeto antropológico. As imagens fazem parte do cotidiano e da realidade vivenciada, e o imaginário é o que dá forma a essas construções. "As máquinas a vapor, as vias férreas, os primeiros automóveis desalojam a maré de silêncio sobre seu percurso ou em suas mediações" (LE BRETON, 2016, p. 139). Atualmente, a antiga estação ferroviária abriga um acervo museológico relacionado ao carvão mineral e, também, um portal de informações turísticas, mostrando que há um patrimônio material que resguarda, também, o patrimônio imaterial. O mitema analisado do apito do trem endossa a importância do símbolo e da função simbólica na vida das pessoas.

\section{About rails: the memory is revised by the train. A study with imaginary lenses}

\begin{abstract}
The Tereza Cristina Railroad, the main link between the municipalities that make up the coal basin in the South of Santa Catarina, was for more than half a century the promoter of the region's development dreams. The whistle of the locomotives and the squealing of the wheels on the iron rails last in the memory of the inhabitants and are constituted as elements that give rise to the imaginary shared by the inhabitants of the regions whose lives were for-
\end{abstract}


ged along the railroad tracks and that, when listening and imagining the great transformations that those whistles could bring to their daily lives or to other people, they dreamed of prosperity. In order to perceive the imaginary function from the image of the train, especially the symbology of its whistle, we heard five residents of the city of Lauro Müller, SC, who experienced the passages of the locomotives. The methodological procedure is based on the descriptive research of a qualitative approach, based on the mitochristic and sensitive observation of the narratives.

Keywords: Imaginary. Memory. Train. Whistle.

\section{Nota}

Dados disponíveis no site da Ferrovia Tereza Cristina: <http://ftc.com.br/a-empresa/historia>. Acesso em: 10 ago. 2017.

\section{Referências}

ABREU, João Batista. Estética do imaginário. In: CONGRESSO BRASILEIRO DE CIÊNCIAS DA COMUNICAÇÃO, 37, Foz do Iguaçu, PR. Anais do Intercom. Foz do Iguaçu, 2014. Disponível em <http://www. intercom.org.br/sis/2014/resumos/R9-2481-2. pdf>. Acesso em: 10 ago. 2017.

ARAÚJO, Alberto Filipe Araújo; MONT'ALVERNE, Iduína. Educar para a imaginação. Revista Memorare, Tubarão, SC, v. 4, n. 2 esp. dossiê II, p.73-105. maio/ago. 2017.

AUGRAS, Monique. Passagem: morte e renascimento. In: PITTA, Danielle Perin da Rocha. $O$ imaginário e a simbologia da passagem. Recife: Massangana, 1984. p. 35-47.
BRESSAN JUNIOR, Mario Abel. A memória afetiva e os telespectadores: um estudo do Canal Viva. Tese (Doutorado em Comunicação Social) - Programa de Pós-Graduação em Comunicação Social, PUCRS, Porto Alegre, 2017. Disponível em <http://hdl.handle. net/10923/10391>. Acesso em: 10 ago. 2017.

BOSI, Ecléa. O tempo vivo da memória. Ensaios de Psicologia Social. 3. ed. São Paulo: 2003.

DURAND, Gilbert. A imaginação simbólica. São Paulo: Cultrix, 1988.

. As estruturas antropológicas do imaginário: introdução à arquetipologia geral. São Paulo: Martins Fontes, 2002.

Exploração do imaginário. In: PITTA, Danielle Perin da Rocha. O imaginário e a simbologia da passagem. Recife: Massangana, 1984. p. 11-32.

FERREIRA SANTOS, Marcos. A sacralidade do texto em culturas orais. Diálogo, São Paulo, a. IX, n. 35, p.14-18, ago. 2004.

FERREIRA SANTOS, Marcos; ALMEIDA, Rogério de. Aproximações ao imaginário: bússolas de investigação poética. São Paulo: Képos, 2012.

GOMES, Eunice Simões Lins. Um baú de símbolos na sala de aula. São Paulo: Paulinas, 2013.

JORON, Philippe. Georg Simmel et la sociologie du futile. Dans les anfractuosités du social et de l'intime. Revista Memorare, Tubarão, SC, v. 4, n. 2 esp., dossiê II, p. 106-121, maio/ago. 2017.

LE BRETON, David. Antropologia dos sentidos. Petrópolis: Vozes, 2016.

LE GOFF, Jacques. História e memória. 5. ed. Campinas, SP: Unicamp, 2003.

MAFFESOLI, Michel. Elogio da razão sensível. 3. ed. Petrópolis: Vozes, 2005.

NORA, Pierre. Entre a memória e a história: a problemática dos lugares. São Paulo: Projeto História, 1993. 
PITTA, Danielle Perin Rocha. Iniciação à teoria do imaginário de Gilbert Durand. Rio de Janeiro: Atlântica, 2005.

PORTO, Maria do Rosário Silveira. Imaginário e cultura: escorrências na educação. In: SILVEIRA, Maria do Rosário et al. (Org.). Tessituras do imaginário: cultura e educação. Cuiabá: Edunic, 2000. p. 17-28.

PRIETO, Benita; FILHO, Francisco Gregório; BRANT, José Mauro. Leitores a caminho. Rio de Janeiro: Editora PUCRio, 2011.

RICOEUR, Paul. A memória, a história, o esquecimento. São Paulo: Editora da Unicamp, 2007.

SILVA, Juremir Machado da. Diferença e descobrimento. $\mathrm{O}$ que é imaginário? (a hipótese do excedente de significação). Porto Alegre: Sulina, 2017.

TEIXEIRA, José Warmuth. Ferrovia Tereza Cristina: uma história de desenvolvimento. 2. ed. Tubarão, SC: edição do autor, 2011.

WUNENBURGER, Jean-Jacques. $O$ imaginário. São Paulo: Loyola, 2007.

ZUMBLICK, Walter. Tereza Cristina: a ferrovia do carvão. Florianópolis: Editora da UFSC, 1987. 